\title{
Tingkat Kinerja Penyuluh Pertanian di Kabupaten Konawe Provinsi Sulawesi Tenggara
}

\section{The Level of Performance of Agricultural Extension in the District of Konawe Southeast Sulawesi Province}

\author{
Syafruddin $^{1}$, Sunarru Samsi Hariadi ${ }^{2}$, dan Sri Peni Wastutiningsih ${ }^{2}$ \\ ${ }^{1}$ Bappeda Kota Kendari Provinsi Sulawesi Tenggara \\ ${ }^{2}$ Sekolah Pascasarjana Universitas Gadjah Mada, Yogyakarta
}

\begin{abstract}
This study aims to provide information on the level of performance of agricultural extension Konawe Southeast Sulawesi and the factors that influence. The unit of analysis This study is of agricultural extension, taken withdrawn in census namely throughout civil servants of agriculture extension worker of the research sites (130 people), while of the objectivity to assess the performance of agricultural extension also taken two farmers who are in the target area so that the number of agricultural extension farmers is 260 people. Data of results in research the analysis use the proportion test, with the provision that the largely the performance level of agricultural extension (> 50\%) in the category which low. Based on the results obtained by the analysis of the proportion test of $Z$ count value as big as -7,89 is smaller than the $Z$ table at $5 \%$ confidence level is equal to 1.960 , then the research hypothesis which states that most of the agricultural extension worker number (> $50 \%$ ) have in low performance level is rejected, because the reality shows that the level of performance of agricultural extension who are being.
\end{abstract}

Keywords: Performance, level, agricultural, extension

Abstrak

Penelitian ini bertujuan untuk memberikan informasi tingkat kinerja penyuluh pertanian di Kabupaten Konawe Provinsi Sulawesi Tenggara dan faktor-faktor yang mempengaruhi. Unit analisis penelitian ini adalah penyuluh pertanian, yang diambil/ditarik secara sensus yaitu seluruh penyuluh pertanian PNS yang ada di lokasi penelitian (sebanyak 130 orang), sedangkan untuk menilai objektivitas kinerja penyuluh pertanian juga diambil 2 petani yang berada di wilayah binaan penyuluh pertanian sehingga jumlah petani adalah 260 orang. Data hasil penelitian dianalisis dengan menggunakan uji proporsi, dengan ketentuan bahwa sebagian besar tingkat kinerja penyuluh pertanian (> 50\%) dalam kategori yang rendah. Berdasarkan hasil analisis uji proporsi diperoleh nilai Z hitung sebesar -7,89 lebih kecil dari Z tabel pada tingkat kepercayaan 5\% adalah sebesar 1,960, maka hipotesis penelitian yang menyatakan sebagian besar jumlah penyuluh pertanian ( $>50 \%)$ mempunyai tingkat kinerja yang rendah ditolak, karena realita menunjukkan bahwa tingkat kinerja penyuluh pertanian yang sedang.

Kata kunci: Kinerja, level, penyuluhan, pertanian

\section{Pendahuluan}

Penyuluhan pertanian sebagaimana diamanahkan dalam UU N0. 16 Tahun 2006 tentang Sistem Penyuluhan Pertanian, Perikanan dan Kehutanan merupakan bagian upaya mencerdasakan bangsa dan memajukan kesejahteraan umum dan pemerintah berkewajiban untuk menyelenggarakannya (Anonim, 2006). Penyuluhan Pertanian dalam UU ini diartikan sebagai proses pembelajaran bagi pelaku utama serta pelaku usaha agar mereka mau dan mampu menolong dan mengorganisasi dirinya dalam mengakses informasi pasar, teknologi, permodalan dan sumber daya lainnya sebagai upaya untuk meningkatkan produktivitas, efisiensi usaha, pendapatan dan kesejahteraan serta meningkatkan kesadaran dalam pelestarian fungsi lingkungan hidup. Olehnya itu penyuluh pertanian dalam pelaksanaan tugas yang diembannya harus berdasarkan pada tugas dan fungsi yang telah ditetapkan.

Seseorang penyuluh dapat dikatakan berkinerja baik, apabila terdapat bukti-bukti atau indikator ukuran tingkat pencapaian yang mengarah pada tercapainya tujuan. Untuk mengetahui kinerja seseorang penyuluh diperlukan adanya suatu penilaian kinerja. Penilaian ini dimaksudkan sejauhmana keberhasilan seorang penyuluh dalam kurung waktu tertentu dan penilaian tersebut dapat dijadikan masukan bagi perbaikan kinerjanya.

Kabupaten Konawe dimana tugas dan fungsi penyuluh pertanian tertuang dalam indikator

\footnotetext{
${ }^{1}$ Korespondensi penulis

E-mail: syafruddin2006@yahoo.co.id
} 
kinerja penyuluh pertanian yaitu (1) menyusun programa penyuluhan, (2) menyusun rencana kerja dan jadwal kunjungan ke wilayah binaan, (3) membuat data dan peta wilayah binaan/wilayah kerja, (4) mendesiminasikan informasi teknologi (penggunaan metode-metode penyuluhan yang tepat), (5) memberdayakan dan kemandirian petani (kemampuan petani dalam menyiapkan berbagai kebutuhan yang dapat menunjang keberhasilan usahatani), (6) menjalin kemitraan usaha dengan unsur-unsur terkait yang dapat mendukung suksesnya usahatani, (7) mewujudkan; (a) akses petani kelembaga keuangan (menyiapkan uang untuk modal usaha), (b) akses petani ke sumber informasi(BPTP, perguruan tinggi, instansi pemerintah lingkup pertanian, perikanan dan kehutanan), (c) akses petani tentang pemasaran hasil (pasar lokal dan eksport), (8) meningkatkan produktivitas agribisnis komoditi unggulan, (9) meningkatkan pendapatan dan kesejahteraan petani (Anonim, 2011; Deptan, 2010). Dalam penelitian ini, indikator kinerja tidak hanya mengacu pada indikator menurut Deptan (2010), melainkan mengkobinasikan dengan beberapa kajian pustaka dan indikator kinerja yang digunakan di lapangan serta hasil-hasil penelitian sebelumnya yaitu responsivitas, responsibilitas, akuntabilitas, kualitas layanan, efektivitas dan efisiensi (Lenvine dkk., 1990); (Swanson, 1997); (Bestina, 2001); (Mokhtar, 2001).

Pada indikator 8 dan 9 yaitu meningkatkan produktivitas agribisnis komoditi unggulan, dan meningkatkan pendapatan dan kesejahteraan petani, bukan satu-satunya indikator untuk mengukur kinerja penyuluh pertanian karena tidak cocok sehingga penulis tidak memasukan sebagai indikator kinerja penyuluh pertanian, tetapi memasukan indikator responsivitas, responsibilitas, akuntabilitas, kualitas layanan, efektivitas dan efisiensi karena sangat cocok/ baik dengan kondisi di lapangan dan ini dibuktikan uji reliabelitas sangat baik yaitu di atas 0,6 atau mendekati nilai 1 .

Meningkatkannya produktivitas agribisnis unggulan di wilayahnya dipengaruhi oleh banyak faktor yang sifatnya tidak dapat direkayasa oleh penyuluh pertanian diantaranya kondisi tanah (tingkat kesuburan), keadaan iklim, curah hujan, dan pengairan non teknis. Untuk mengukur tingkat pendapatan petani dapat diukur dari jumlah produksi dan harga jual, sedangkan untuk mengukur kesejahteraan dapat diukur dari pengembangan struktur pendapatan, perkembangan pengeluaran untuk pangan dan perkembangan nilai tukar petani (NTP). Jumlah produksi tidak dapat ditentukan oleh penyuluh, tetapi ditentukan oleh luas lahan dan modal usahatani.

Dengan demikian, kedua indikator tersebut tidak pas atau tidak relevan sebagai indikator yang digunakan untuk mengukur kinerja penyuluh pertanian. Memahami ukuran kinerja sangat penting dalam rangka meningkatkan kinerja kinerja penyuluh pertanian. Oleh karena itu seorang penyuluh pertanian dituntut tidak hanya memiliki bekal pengetahuan, keterampilan teknis yang memadai, tetapi juga dituntut kemampuan melaksanakan tugas pokok dan fungsi yang tercakup dalam indikator kinerja penyuluh pertanian, agar proses dan kegiatan penyuluhan lebih optimal.

Kabupaten Konawe saat initerdapat 130penyuluh pertanian PNS, yang terdiri dari 91 orang penyuluh tanaman pangan, 25 orang penyuluh perkebunan, dan 14 orang penyuluh peternakan. Jika dilihat dari jumlah desa/ kelurahan binaan yang ada yaitu sebanyak 370 desa/ kelurahan, ini berarti bahwa jumlah penyuluh pertanian di Kabupaten Konawe sesuai amanahUUNo. 16 Tahun 2006 yaitu satu desa satu penyuluh belum terpenuhi imbang, sehingga memungkinkan kinerja penyuluh pertanian belum optimal. Selanjutnya informasi yang diperoleh dari Badan Koodinasi Penyuluhan Pertanian, Perikanan, dan Kehutanan Provinsi Sulawesi Tenggara menyatakan kinerja penyuluh pertanian Sulawesi Tenggara belum sepenuhnya baik atau masih rendah. Selain itu belum pernah dilakukan penelitian yang komprehensif tentang penilaian tingkat kinerja penyuluh pertanian di Sulawesi Tenggara, termasuk Kabupaten Konawe sebagai salah satu sentra produksi pertanian andalam. Dari uraian tersebut di atas, maka dipandang perlu untuk meneliti tingkat kinerja penyuluh pertanian di Kabupaten Konawe.

Berdasarkan latarbelakang, maka yang menjadi permasalahannya adalah seberapa besar tingkat kinerja penyuluh pertanian di Kabupaten Konawe dan faktorfaktor yang mempengaruhi. Tujuan penelitian ini adalah untuk memberikan informasi tingkat kinerja penyuluh pertanian di Kabupaten Konawe dan faktorfaktor yang mempengaruhi.

\section{Kajian Teori}

Kinerja (performance) mempunyai pengertian sebagai unjuk kerja atau prestasi suatu lembaga dalam melaksanakan suatu pekerjaan, tugas atau fungsinya selama waktu tertentu (Meier; portend 
and Lawyer dalam As'ad, 1991; Atmosudirjo, 1993; Bernandin dan Russel, 1993; Prayudi, 1997; Keban, 2004).

Penilaian tingkat kinerja yang ada melihatnya dari responsivitas, responsibilitas, akuntabilitas, kualitas layanan dan produktivitas (Lenvine et al., 1990; Bestina, 2001; Mokhtar, 2001); efektivitas, dan efisiensi (Swanson, 1997); Deptan (2010) (1) tersusunnya programa penyuluhan pertanian, (2) tersusunnya rencana kerja tahunan(RKT) penyuluh pertanian, (3) tersusunnya data peta wilayah untuk pengembangan teknologi spesifik lokasi, (4) terdesiminasinya informasi teknologi pertanian secara merata, (5) tumbuhkembangnya keberdayaan dan kemandirian pelaku utama dan pelaku usaha, (6) terwujudnya kemitraan usaha pelaku utama dan pelaku usaha yang menguntungkan, (7) terwujudnya akses pelaku utama dan pelaku usaha kelembaga keuangan, informasi, sarana produksi, (8) meningkatnya produktivitas agribisnis komoditas unggulan di wilayahnya, (9) meningkatnya pendapatan dan kesejahteraan pelaku utama.

Faktor-faktor yang mempengaruhi kinerja dapat digunakan instrumen penilaian kinerja yang tentunya akan berbeda-beda. Moorhead dan Griffin dalam Suwito (2005) menyatakan bahwa motivasi/ motivation (M) secara bersama-sama dengan kemampuan/ability (A) dan lingkungan/ environment (E) akan mempengaruhi kinerja seseorang, dirumuskan dengan $\mathrm{P}=(\mathrm{M} \times \mathrm{A} \times \mathrm{E})$. Kinerja $(\mathrm{P})$ yang tinggi akan diperoleh jika individu mempunyai motivasi $(\mathrm{M})$ untuk melakukan pekerjaan, mempunyai kemampuan (A) melakukan pekerjaan dan didukung oleh sarana dan prasarana yang diperlukan untuk melakukan pekerjaan tersebut(E). Pendapat lain bahwa kinerja dipengaruhi oleh interaksi dua faktor yaitu faktor kemampuan dan motivasi, yang dapat dirumuskan; Performance $=f$ (abilityx motivation) (Vroom, 1964; hoy \& Miskel dalam Rahardja, 2004); selain dipengaruhi oleh kapasitas dan motivasi tetapi juga oleh kesempatan yang diberikan oleh suatu situasi atau lingkungan, yang dapat dirumusan adalah; Performance $=f$ (Opportunities x Capasity x Willingness) (Blumberg \& Pringle, 1982); fungsi dari motivasi (motivation), kemampuan (capasity), kesempatan (opportunities), dan lingkungan (environment) (Umstot, 1988); fungsi dari motivasi, kemampuan, persepsi, ciri-ciri personil, sistem organisasi (struktur organisasi, kepemimpinan, sistem imbalan) dan sumber daya (fasilitas fisik) (Amold dan Feldman, 1986); faktor situasi (situational factors) (Kane, 1993); organizational capasity, organizational motivation, and environment (Luthaus dan Adrien, 1998); Pengaruh kebijakan (Mahmudi, 2004); kapasitas manajemen, (Ingraham and Donahue, 2003); faktor lingkungan, karakteristik klien, teknologi, struktur organisasi, serta peran dan kegiatan organisasi (Hill andLynn, 2004); faktorinternal;(1)strategi organisasi (strategy), (2) struktur organisasi (structur), (3) sistem kerja organisasi (System) (4) staf organisasi (staff), (5) gaya kepemimpinan organisasi (Style) dan kemampuan/keterampilan (skil), (6) nilai-nilai bersama dalam organisasi, dan faktor eksternal; (1) idiologi atau kepercayaan, (2) politik, (3) ekonomi, (4) sosial budaya, (5) lingkungan geografis dan (6) kondisi keamanan dan (7) ketertiban dilingkungan masyarakat dimana organisasi tersebut berada (Parkhatin, 2003); faktor internal (organisasi, dan SDM) dan faktor eksternal (jaringan tugas/dukungan antar lembaga, pengaruh lingkungan baik, ekonomi, politik maupun sosial) (Fardiaz et al., 1999); faktorfaktor internal penyuluh seperti umur, pendidikan, masa kerja, motivasi, penghargaan dan karakteristik petani (motivasi bertani, partisipasi bertani) dan faktor-faktor eksternal berupa supervisi, kondisi kerja, dan hubungan interpersonal (Yusri, 1999).

Hasil penelitian Rohmani (2001); Bestina (2001); Jahi Amri (2006) yang menyatakan bahwa kinerja penyuluh pertanian adalah dalam kategori sedang (belum optimal). Menurut Rohmani (2001) faktor internal yang memberi pengaruh sangat nyata terhadap kinerja penyuluh pertanian adalah jenjang jabatan fungsional, umur, golongan, dan masa kerja, sedangkan faktor eksternal yang berpengaruh adalah komoditi dominan di wilayah binaan. Berbeda dengan hasil penelitian Bestina (2001) yang menunjukkan bahwa faktor motivasi, kemampuan dan partisipasi dalam dalam proses kegiatan usahatani berpengaruh sangat nyata, sedangkan ketepatan program, ketersediaan teknologi dan kesesuaian pelatihan bagi penyuluh tidak berpengaruh terhadap kinerja.

Selanjutnya hasil penelitian Mokhtar (2001); Ibrahin (2001) menunjukkan bahwa kinerja penyuluh pertanian yang dilihat dari indikator responsivitas, responsibilitas dan kualitas layanan kepada petani belum optimal yaitu masih tergolong rendah karena belum memenuhi kebutuhan petani. Lebih lanjut menurut Ibrahin (2001) rendahnya kinerja penyuluh 
pertanian tersebut disebabkan oleh keistimewaan jasa penyuluhan (daya saing, keahlian fungsional dan kekritisan) yang merupakan kebutuhan paling penting bagi petani belum tercapai.

Davis dan Newstrom (1989) mengemukakan bahwa variabel yang mampu mempengaruhi tingkat prestasi dan kinerja organisasi adalah kewenangan organisasi, sumberdaya manusia dan keadaan lingkungan organisasi. Selanjutnya Stonner dan Freeman (1992) menjelaskan bahwa ada dua faktor yang dapat menunjang kinerja suatu organisasi yaitu lingkungan organisasi dan dukungan sumberdaya organisasi. Penilain kinerja penyuluh dalam penelitian ini mengacu pada berbagai pustaka dan teori yang dikemukakan oleh (Meier; portend and lawyer dalam As'ad, 1997; Atmosudirjo, 1993; Bernandian dan Ruseel, 1998; Prayudi, 1997; dan Keban, 2004) yang memberikan pengertian kinerja adalah unjuk kerja, hasil kerja atau prestasi kerja dalam melaksanakan sutau pekerjaan, tugas atau fungsinya selama waktu tertentu.

Oleh karena itu, penilaian kinerja bagi seorang penyuluh merupakan perwujudan diri atas sejauhmana tugas pokok dan fungsi dapat dilaksanakan sesuai dengan indikator yang ditetapkan, bukan hanya mengacu pada indikator menurut Deptan (2010) yaitu (1) tersusunnya program penyuluhan pertanian, (2) tersusunnya rencana kerja tahunan (RKT) penyuluh pertanian, (3) tersusunnya data peta wilayah untuk pengembangan teknologi spesifik lokasi, terdesiminasinya informasi teknologi pertanian secara merata, (5) tumbuhkembangnya keberdayaan dan kemandirian pelaku utama dan pelaku usaha, (6) terwujudnya kemitraan usaha pelaku utama dan pelaku usaha yang menguntungkan, (7) terwujudnya akses pelaku utama dan pelaku usaha kelembaga keuangan, informasi dan sarana produksi, melainkan berdasarkan indikator kinerja dari berbagai kajian pustaka dan yang digunakan dilapangan, yaitu indikator (8) responsivitas penyuluh, (9) responsibilitas penyuluh, (10) akuntabilitas penyuluh,(11) kualitas layanan penyuluh, (12) efisiensi penyuluh dan (13) efektivitas penyuluh.

Tingkat kinerja penyuluh pertanian dipersepsikan diduga dipengaruhi dua faktor yaitu faktor pendukung yaitu insetif, tingkat kepercayaan petani, dan kenaikan pangkat, dan faktor penghambat pembinaan karir, tingkat kepercayaan penyuluh terhadap kebijakan organisasi, dan kejelasan tugas/ wewenangan. Dengan demikian, penilain tingkat kinerja penyuluh pertanian sangat penting karena dengan adanya penilaian tersebut diharapkan dapat diketahui tingkat keberhasilan penyuluh dalam tugas pokok dan fungsi dalam kurung waktu tertentu sesuai dengan indikator kinerja yang ditetapkan.

\section{Metode Penelitian}

Penelitian ini dilaksanakan di Kabupaten Konawe, dengan metode yang digunakan adalah dengan pendekatan penelitian kuantitatif yang didukung dengan penelitian kualitatif (Tashakkori, 1998). Unit analisis yang digunakan untuk mengukur tingkat kinerja penyuluh pertanian adalah penyuluh pertanian yang ada di Kabupaten Konawe yang diambil/ditarik secara sensus sebanyak 130 orang, sedangkan untuk menilai objektivitas kinerja penyuluh pertanian juga diambil 2 petani yang berada di wilayah binaan penyuluh yang mengetahui persis kinerja penyuluh pertanian sehingga jumlah petani adalah 260 orang. Hal ini dilakukan untuk mengkonfirmasi atau mengkroscek jawaban yang diberikan oleh penyuluh dengan kuesioner yang sama, apakah jawaban yang diberikan oleh penyuluh itu sudah sesuai dengan kondisi atau keadaan penyuluh di lapangan dalam pelaksanaan tugasnya. Selanjutnya dilakukan pengukuran dengan teknik skoring model skala likert. Skor jawaban penyuluh dan petani dirata-rata sehingga menjadi satu nilai variabel kinerja penyuluh pertanian.

Teknik pengumpulan data dalam penelitian ini dilakukan dengan cara yaitu (1) Data primer, dengan cara menyebarkan kuesioner untuk memenuhi data kuantitatif, (2) wawancara, yaitu dilakukan secara mendalam kepada penyuluh pertanian PNS, kepala BP4K, koordinator penyuluh kabupaten, dan petani dengan menggunakan pedoman wawancara, yang bertujuan mendapatkan infor-masi secara mendalam, (3) pencatatan, yaitu pengumpulan data dengan cara mencatat hal-hal yang belum tercantum dalam daftar pertanyaan (kuesioner), (4) observasi, yaitu pengumpulan data dengan mengamati secara langsung penyuluh pertanian dan petani untuk melengkapi data yang diperoleh dari hasil wawancara dan pencatatan. Teknik analisis data dalam penelitian ini digunakan analisis data kuantitatif dan analisis data kualitatif. Untuk data yang bersifat kuantitatif digunakan analisis uji proporsi (Sugiono, 2007). 


\section{Hasil dan Pembahasan}

Kinerjapenyuluhpertaniandiukurberdasarkan tiga belas indikator kinerja penyuluh pertanian, sebagaimana disajikan pada Tabel 1. Berdasaran Tabel 1, tingkat persentase capaian kinerja penyuluh pertanian di Kabupaten Konawe secara keseluruhan adalah sebesar 59,30\%. Hasil ini mengidikasikan bahwa tingkat persentase capaian ketiga belas indikator penilaian tingkat kinerja penyuluh pertanian termasuk dalam kategori yang cukup baik. Tingkat kinerja penyuluh pertanian diperoleh dari skor jawaban pertanyaan, lalu ditentukan skor maksimal dan minimal yang kemudian dibagi dalam tiga kategori yaitu rendah, sedang dan tinggi, dengan menggunakan rumus interval, disajikan pada Tabel 2.

Berdasarkan Tabel 2 menunjukkan bahwa tingkat kinerja penyuluh pertanian di Kabupaten Konawe Provinsi Sulawesi Tenggara tergolong dalam kategori yang sedang. Hal ini juga ditunjukkan hasil analisis uji proporsi, diperoleh nilai $\mathrm{Z}$ hitung sebesar -7,89 lebih kecil dari $Z$ tabel pada tingkat kepercayaan $5 \%$ adalah sebesar 1,960, maka hipotesis penelitian yang menyatakan sebagian besar jumlah penyuluh pertanian ( $>50 \%$ ) mempunyai tingkat kinerja yang rendah ditolak, karena realita menunjukkan tingkat kinerja penyuluh pertanian yang sedang.

Hasil penelitian ini (Tabel 1) memberikan suatu perspektif bahwa kinerja penyuluh pertanian di Kabupaten Konawe dalam pelaksanaan 13 indikator kinerja penyuluh pertanian, ada 5 indikator yang sering dilaksanakan dan paling penting yaitu (1) menyusun programa penyuluhan pertanian dengan presentase capaian sebesar 78,68\%, (2) menyusun rencana kerja dan jadwal kunjungan ke wilayah binaan dengan presentase capaian sebesar $72,38 \%$, (3) membuat data dan peta wilayah binaan/wilayah kerja dengan presentase capaian sebesar $64,85 \%$, (4) responsibilitas penyuluh dengan presentase capaian sebesar $68,13 \%$, dan (5) akuntabilitas penyuluh dengan presentase capaian sebesar $60,16 \%$, sedangkan 8 indikator lainnya yaitu kadang-kadang dilaksanakan oleh penyuluh pertanian yaitu (1) mendiseminasikan informasi teknologi (penggunaan metode penyuluhan pertanian yang tepat) dengan presentase capaian sebesar 57,98\%, (2) memberdayakan dan memandirikan pelaku utama dengan presentase capaian sebesar $59,18 \%$, (3) menjalin kemitraan usaha dengan unsur-unsur terkait yang dapat mendukung suksesnya usahatani dengan presentase capaian sebesar $42,41 \%$, (4) mewujudkan akses pelaku utama ke lembaga keuangan, sumbersumber informasi, sarana produksi dan pemasaran hasil dengan presentase capaian sebesar 40,67\%, (5) responsivitas penyuluh pertanian dengan presentase capaian sebesar $55,87 \%$, (6) kualitas penyuluh pertanian dengan presentase capaian sebesar 57,37\%, (7) efisiensi penyuluh pertanian dengan presentase capaian sebesar $58,45 \%$, dan (8) efektivitas penyuluh pertanian dengan presentase capaian sebesar $59,67 \%$.

Berdasarkan hasil penelitian, pengamatan dan wawancara di lapangan didapatkan informasi bahwa 5 indikator yang sering dilaksanakan dan paling penting tersebut karena penyuluh pertanian cenderung menyikapi ke lima indikator tersebut dengan sangat positif. Hal ini terungkap dari hasil identifikasi dimana rata-rata penyuluh pertanian di Kabupaten Konawe memiliki data topografi desa yang merupakan output dari kegiatan identifikasi potensi wilayah yang dilakukan oleh penyuluh pertanian dan juga memiliki programa penyuluhan desa. Output hasil identifikasi potensi wilayah tersebut yang akan digunakan oleh institusi BP4K Kabupaten Konawe dalam penyusunan programa penyuluhan, perencanaan dan bahan evaluasi pemerintah daerah dalam rangka mencapai tujuantujuan kebijakan pembangunan pertanian. Hasil penelitian ini sejalan dengan hasil penelitian Hamzah (2011) bahwa rata-rata penyuluh sangat kompeten dalam perencanaan programa penyuluhan seperti indentifikasi potensi wilayah, penyusunan programa dan rencana kerja tahunan.

Hasil penelitian yang sama sebagaimana dilaporkan oleh Kusnadi, (2010) yang menyatakan bahwa kinerja penyuluh pertanian menurut persepsi petani di Bp3K Kayuara secara umum termasuk kategori yang sedang. Selanjutnya dikatakan bahwa enam dari sembilan indikator kinerjapenyuluhmenurut persepsi petani termasuk kategori yang sedang yaitu (1) memfasilitasi penumbuhan dan pengembangan kelompoktani/gapoktan, (2) bimbingan pemecahan masalah,(3)mengiventalisir/mengidenfikasi potensi wilayah, (4) mengembangkan swadaya dan swakarsa, (5) membuat catatan/penyusunan laporan, (6) memfasilitasi forum penyuluhan, sedangkan indikator yang termasuk kedalam kategori yang baik, yaitu memotivasi petani dalam berusahatani, serta dua indikator termasuk dalam kategori yang rendah 
Tabel 1 Distribusi Tingkat Kinerja Penyuluh Pertanian, di Kabupaten Konawe Provinsi Sulawesi Tenggara Tahun 2012

\begin{tabular}{|c|c|c|c|c|}
\hline No & Deskripsi Kinerja Penyuluh Pertanian & $\begin{array}{c}\text { Interval } \\
\text { Skor }\end{array}$ & $\begin{array}{l}\text { Skor } \\
\text { Capain }\end{array}$ & $\begin{array}{l}\text { Persentase } \\
\text { (\%) }\end{array}$ \\
\hline 1. & Menyusun programa penyuluhan pertanian & $0-28,8$ & 21,15 & 73,68 \\
\hline 2. & Menyusun rencana kerja dan jadwal kunjungan ke wilayah binaan & $0-38,4$ & 28,10 & 72,38 \\
\hline 3. & Membuat data dan peta wilayah binaan/wilayah kerja & $0-26,0$ & 16,97 & 64,95 \\
\hline 4. & $\begin{array}{l}\text { Mendisemilasi informasi teknologi pertanian (penggunaan metode } \\
\text { penyuluhan yang tepat) }\end{array}$ & $0-28,2$ & 16,55 & 57,98 \\
\hline 5. & $\begin{array}{l}\text { Memberdayakan dan memandirikan pelaku utama (kemampuan } \\
\text { pelaku utama dalam menyiapkan berbagai kebutuhan yang dapat } \\
\text { menunjang keberhasilan usahatani }\end{array}$ & $0-30,0$ & 17,92 & 59,18 \\
\hline 6. & $\begin{array}{l}\text { Menjalin kemitraan usaha dengan unsur-unsur terkait yang dapat } \\
\text { mendukung suksesnya usahatani. }\end{array}$ & $0-31,1$ & 13,45 & 42,41 \\
\hline 7. & $\begin{array}{l}\text { Mewujudkan akses pelaku utama dan pelaku usaha ke lembaga } \\
\text { keuangan, sumber informasi, sarana produksi, dan pemasaran hasil }\end{array}$ & $0-37,3$ & 16,66 & 40,67 \\
\hline 8. & Responsivitas penyuluh & $0-27,7$ & 15,81 & 55,87 \\
\hline 9. & Responsibilitas penyuluh & $0-32,0$ & 21,15 & 68,13 \\
\hline 10. & Akuntabilitas penyuluh & $0-26,7$ & 15,81 & 60,16 \\
\hline 11. & Kualitas Layanan penyuluh & $0-28,0$ & 16,10 & 57,37 \\
\hline 12. & Efisiensi penyuluh & $0-34,7$ & 20,23 & 58,45 \\
\hline 13. & Efektivitas penyuluh & $0-32,4$ & 19,33 & 59,67 \\
\hline \multicolumn{2}{|c|}{ Jumlah } & $0-401,4$ & 239,25 & 59,30 \\
\hline
\end{tabular}

Sumber: Analisis Data Primer, 2012

yaitu penyebarluasan informasi dan memfasilitasi forum penyuluhan.

Begitu pula dengan hasil penelitian Suhanda (2008) yang mengukur kinerja pelaksanaan tugas penyuluh pertanian di Jawa Barat, dengan mengkaji unsur-unsur kinerja berdasarkan (1) pelibatan tokoh masyarakat, (2) penumbuhkembangan kelompok tani, (3) penyusunan rencana kerja penyuluhan, (4) penerapan metode penyuluhan, (5) penyusunan programa, (6) penyusunan materi, (7) penumbuhan keswadayaan dan keswakarsaan, (8) tata laksana kantor, (9) penumbuhan kelembagaan ekonomi, (10) analisa potensi dankebutuhan,(11) evaluasi dan pelaporan,(12) pengembangan jejaring (13) dan (14) pengembangan professional. Hasil temuan menunjukkan bahwa skor terendah kinerja penyuluh pertanian di Jawa Barat pada unsur kinerja pengembangan profesionalisme dan skor tertinggi pada pelibatan tokoh masyarakat. Secara keseluruhan kinerja penyuluh pertanian di Jawa Barat ada pada kategori sedang dalam skala tiga yaitu buruk, sedang, dan baik. Selanjutnya berdasarkan hasil penelitian Jamal (2010) dengan melakukan penelitian kinerja penyuluh pertanian lapangan di Provinsi Jambi, mengukur penilaian tingkat kinerja berdasarkan bobot setiap kegiatan penyuluhan yaitu (1) persiapan penyuluhan; (a) identifikasi potensi wilayah, (b) memandu penyusunan rencana kerja usaha petani, (c) penyusunan rencana kerja penyuluhan pertanian tahunan, (2) pelaksanaan penyuluhan pertanian; (a) penyusunan materi pertanian, (b) perencananaan dan penerapan metode penyuluhan pertanian; (i) kujungan tatapmuka/anjangsana perorangan, (ii) kunjungan tatap muka/anjangsana kelompok, (iii) kunjungan tatap muka/anjangsana missal, (iv) uji coba dan demonstrasi, (v) temu, pameran, dan lomba, (vi) karya wisata, mimban sarasehan dan magang, (vii) kursus tani, (viii) penumbukan penyuluh swadaya, (c) menumbuhkan/mengembangkan kelembagaan petani; (i) menumbuhkan kelompok tani baru, (ii) meningkatkan kelas kelompok tani, (iii) memfasilitasi kerjasama kelompok tani, (3) evaluasi dan pelaporan; (a) evaluasi pelaksanaan penyuluhan, (b) pelaporan pelaksanaan kegiatan penyuluhan. Berdasarkan hasil temuan menunjukkan bahwa dari tiga penilaian kinerja kegiatan penyuluhan diperoleh tingkat kinerja yang terendah pada aspek evaluasi dan pelaporan. Lebih lanjut hasil penelitian ini tidak ditemui penyuluh yang menyusun evaluasi terhadap pelaksanaan maupun 
Tabel 2 Distribusi Tingkat Kinerja Penyuluh Pertanian di Kabupaten Konawe Provinsi Sulawesi Tenggara Tahun 2012

\begin{tabular}{lcc}
\hline \multicolumn{1}{c}{ Klasifikasi tingkat Kinerja } & Jumlah Penyuluh & Persentase \\
& (jiwa) & (\%) \\
\hline Rendah & 2 & 1,54 \\
Sedang & 79 & 60,77 \\
Tinggi & 49 & 37,69 \\
\hline J u m l a h & 130 & 100,00 \\
\hline
\end{tabular}

Sumber : Analasis Data Primer, 2012

dampak kegiatan penyuluhan yang mereka lakukan. Hal ini menunjukkan bahwa aktivitas mengevaluasi dan melaporkan hasil pelaksanaan dan dampak penyuluhan pertanian belum menjadi bagian integral dari rangkaian penyelenggaraan penyuluhan oleh penyuluh. Pada sub kegiatan penerapan metode penyuluhan, kunjungan tatapmuka/anjangsana (perorangan, kelompok dan massal) merupakan kegiatan utama sebagai sarana bagi penyuluhan untuk melakukan komunikasi timbal balik dengan pelaku utama dan usaha di wilayah binaan. Kinerja penyuluh pertanian lapangan di Provinsi Jambi berada pada kategori yang rendah.

Hasil penelitian ini juga didukung oleh hasil penelitian Bestina (2001); Mokhtar (2001), Supandi (2002); Suhanda dkk (2008) yang menyatakan bahwa kinerja penyuluh pertanian dalam melaksanakan tugasnya masih masih dalam kategori yang sedang, sedangkan hasil penelitian Ibrahin (2001); Suryaman dalam (Tjitropranoto, 2001); Jahi Amri (2006); Marius (2006); Utami dkk (2008); Sumardjo (2010); Hamzah (2011) yang menolak hasil penelitian tersebut, yaitu kinerja penyuluh pertanian adalah masih dalam kategori yang rendah atau kurang baik. Sebagaimana telah dijelaskan di atas, berdasarkan hasil analisis uji proporsi dan analisis deskriptif tampak bahwa kinerja penyuluh pertanian di Kabupaten Konawe menunjukkan tingkat kinerja yang sedang. Hal ini dapat diasumsikan, belum menerapkan unsur-unsur kinerja penyuluh pertanian secara penuh. Berdasarkan hasil penelitian, wawancara secara mendalam kepada kepala BP4K, koordinator penyuluh kabupaten, penyuluh pertanian dan petani, dan observasi di lapangan terungkap bahwa ada dua faktor yang mempengaruhi yaitu faktor pendukung dan faktor penghambat. Faktor pendukung adalah adanya insentif dalam bentuk piagam penghargaan, kepercayaan petani terhadap penyuluh pertanian dan proses kenaikan pangkat/ kepangkatan, sedangkan faktor penghambat adalah pembinaan karir, tingkat kepercayaan penyuluh terhadap kebijakan organisasi, kejelasan tugas/ wewenang, dan rasio penyuluh dengan jumlah desa/kelurahan binaan. Untuk lebih jelasnya dapat disajikan pada beberapa faktor berikut yaitu:

Insentif; merupakan salah satu sistem reward yang mempunyai tujuan memotivasi pegawai untuk lebih meningkatkan prestasi kinerjanya. Insentif adalah tambahan balas jasa yang diberikan kepada karyawan tertentu yang prestasinya di atas prestasi kerja (Hasibuan, 2000; Simamora, 1999).

Berdasarkan hasil penelitian, pengamatan dan wawancara dengan penyuluh di lapangan terungkap bahwa insentif yang diterima dan dirasakan oleh penyuluh selama ini yaitu berupa bantuan operasional penyuluh (BOP) dan piagam penghargaan kepada penyuluh yang berprestasi. Bantuan operasional penyuluh (BOP) yang diterima oleh pemerintah pusat yaitu sebesar Rp 250.000/ bulan dan dari APBD berupa transpor lokal Rp 150.000/bulan yang dibayarkan per tiga bulan. Informasi yang diterima BOP yang selama ini diberikan oleh pemerintah pusat kepada penyuluh pertanian secara merata di setiap (BP4K) yang ada di Indonesia termasuk BP4K Kabupaten Konawe, menurut tanggapan penyuluh belum layak dan belum menunjukkan asas keadilan karena tidak mempertimbangkan kondisi topografi atau tingkat kesulitan aksesbilitas di lapangan, pada hal setiap daerah mempunyai kondisi topografi yang berbeda-beda dengan tingkat keterjangkauan yang berbeda pula, sementara BOP yang diberikan sama. Semestinya besaran BOP yang diberikan kepada penyuluh disesuaikan dengan kondisi topografi masingmasing daerah setempat atau berdasarkan jumlah dan luas wilayah binaan. BOP yang terima tersebut tidak 
seimbang dengan beban kerja, dimana satu orang penyuluh di Kabupeten Konawe harus melayani/ membina (2-3) desa/kelurahan, sementara penyuluh lain yang hanya melayani/membina $1 \mathrm{desa} /$ kelurahan dengan tingkat kesulitan yang sama dengan BOP yang sama. Para penyuluh mengharapkan ada tambahan dana operasional baik berasal dari APBD kabupaten, APBD provinsi dan dari APBN. Oleh karena itu peneliti menyarankan agar kebijakan tersebut perlu ditinjau kembali, agar BOP yang diberikan kepada setiap penyuluh pertanian berdasarkan pada beban kerja/luas wilayah atau tingkat kesulitan aksesbilitas yang menjadi binaan penyuluh pertanian. Fakta sebaliknya menunjukkan bahwa, terhadap fungsional lain yang bertugas di daerah terpencil seperti guru, mendapatkan tunjungan/BOP daerah terpencil.

Besaran BOP dari pemerintah pusat tersebut sesuai dengan yang telah diamanahkan Undang Undang Nomor 16 Tahun 2006 tentang Sistem Penyuluhan Pertanian, Perikanan, dan Kehutanan, Bab. IX Pasal 32 mengenai pembiayaan, dan diperkuat dengan Peraturan Pemerintah Nomor 43 Tahun 2009 tentang Pembiayaan, Pembinaan dan Pengawasan Penyuluh Pertanian, Perikanan dan Kehutanan Pasal 7 mengenai biaya operasional penyuluh pegawai negeri sipil (PNS). Maka menjadi kewajiban Kementerian Pertanian sebagai instansi pembina penyuluh Pertanian untuk memberikan dukungan operasional dengan menyediakan anggaran berupa biaya operasional penyuluh pertanian.

Insentifdalam bentukpemberian pengharagaan kepada para penyuluh yang berprestasi, dilakukan setiap tahunnya, bersamaan dengan adanya pemilihan penyuluh berprestasi/teladan dalam rangka mewakili daerah pada tingkat nasional. Penyuluh pertanian berprestasi diawali pemilihan tingkat kabupaten/ kota, provinsi dan selanjutnya pada tingkat nasional (penyuluh teladan tingkat nasional), yang akan diundang oleh bapak presiden pada upacara peringatan hari Kemerdekaan Republik Indonesia di Istana Negara setiap tangal 17 Agustus pada setiap tahunnya. Inilah salah satu harapan para penyuluh bekerja dengan baik agar mereka bisa terpilih sebagai penyuluh berprestasi.

Dengan demikian, adanya insentif merupakan salah satu faktor motivasi/pendorong bagi penyuluh agar bekerja dengan baik. Hal ini sejalan dengan pendapat Safitri (2008) yang menyatakan bahwa pemberian insentif terhadap pegawai adalah sebagai pendorong yang dapat memotivasi pegawai untuk lebih bekerja secara efektif dan berpengaruh positif terhadapprestasikerja(kinerja).Dengandiberikannya insentif yang berupa penghargaan sesuai dengan standar kerja yang telah ditentukan, hal ini berarti memberikan kepuasan kepada pegawainya dan membuat suatu hubungan yang semakin kuat antara pegawai dan institusi tempat penyuluh bekerja. Hasil tersebut sejalan dengan pernyataan Ban (1999) bahwa sangat penting memberikan penghargaan kepada penyuluh yang berhasil melakukan tugasnya dengan baik, karena seorang penyuluh akan melihat rekannya memperoleh promosi karena berhasil melakukan tugas akan cenderung untuk melakukan hal yang sama.

Berdasarkan pendapat di atas, maka salah satu upaya untuk meningkatkan motivasi dan kinerja penyuluh adalah dengan memberikan insentif berupa penghargaan kepada penyuluh yang berprestasi (teladan), BOP atau dalam bentuk yang lain. Tingkat kepercayaan petani; faktor kepercayaan sangatpenting dalam kehidupan bermasyarakat. Dengan saling percaya orang bisa bekerja sama karena kesediaan mereka mementingkan kepentingan kelompoknya. Menurut Fukuyama, (2002) jika para anggota kelompok itu masing-masing mengharapkan bahwa anggota-anggota yang lain akan berperilaku jujur dan terpercaya, maka mereka saling mempercayai.

Berdasarkan hasil penelitian, pengamatan dan wawancara di lapangan kepada penyuluh pertanian dan petani menunjukkan bahwa tingkat kepercayaan petani terhadap penyuluh pertanian di Kabupaten Konawe sudah baik. Menurut petani, penyuluh selama ini telah banyak mengajarkan pengetahuan, keterampilan, mendampingi, dan membantu memecahkan masalah yang mereka hadapi. Kehadiran penyuluh di lapangan selalu mendapat respon positif dari masyarakat setempat. Secara psikologis, hampir semua penyuluh pertanian menyatakan bahwa mereka merasa bangga menjadi penyuluh yang acap diapresiasikan oleh banyak pihak sebagai ujung tombak pembangunan pertanian. Dan mereka juga memiliki relasi sosial yang baik dengan kelompok tani binaan, termasuk dengan aparat desa dan tokoh masyarakat setempat, sehingga ada perasaan nyaman dan aman secara hubungan sosial. Hubungan sosial terjadi karena komitmen positif antara petani dan penyuluh, antar anggota kelompok dan kelompok lainnya maupun kelompok dengan lembaga-lembaga yang lain yang 
kemudian akan menumbuhkan jaringan kerjasama. Petani dominan memperoleh informasi teknologi dari penyuluh yang menyebabkan berkembangnya jaringan komunikasi dengan lembaga sarana produksi maupun sumber informasi lainnya. Kedekatan petani dengan terhadap penyuluh pertanian melalui jaringan komunikasi dan hubungan sosial karena terjadi pertukaran informai antar petani dan penyuluh karena dilandasi pada suatu tujuan bersama, saling mempercayai satu dengan yang lain dan perasaan yakin, bahwa adanya penyuluh akan memberikan respon yang diharapkan dan saling mendukung dalam proses pelaksanaan penyuluhan dan dalam proses pembinaan kelompok tani.

Dalam proses pembinaan kelompok tani, data dari BP4K Kabupaten Konawe pada tahun 2012 pada saat penelitian ini dilakukan tercatat bahwa 1.931 kelompok tani yang tersebar pada 30 Kecamatan, yang terdiri dari 1.649 kelas kelompok pemula, 255 kelas kelompok tani lanjut, 27 kelas kelompok madya, sedangkan kelas kemopok tani utama belum ada, dan seteap tahunnya terus mengalami peningkatan. Hal ini terwujud karena adanya saling percaya dari petani, kelompok tani baik sebagai individu maupun sebagai anggota kelompok tani yang relatif kuat dalam mewujudkan kerjasama.

Hasil penelitian ini juga didukung hasil penelitiaan Sumardjo (2010) bahwa kegiatan penyuluhan dikatakan berhasil manakala program yang disampaikan penyuluh mendapat dukungan dan partisipasi aktif seluruh masyarakat, yang tercermin dari tindakan masyarakat ke arah perbaikan kehidupan keluarganya. Kenaikan pangkat; berdasarkan hasil penelitian dan wawancara dan pengamaan di lapangan menunjukkan bahwa prosedur kenaikan pangkat penyuluh pertanian di Kabupaten Konawe sifatnya relatif tergantung pada penyuluhnya, artinya kalau penyuluh rajin menjalankan tugas dan mampu mengumpulkan kredit point yang disyaratkan, maka proses kenaikan pangkat akan semakin lancar atau tidak hambatan dan sebaliknya bila penyuluh malas menjalangkan tugas atau tidak dapat mengumpulkan kredit point yang disyaratkan dengan sendirinya, maka akan menghambat proses kenaikan pangkatnya. Dari setiap butir kegiatan yang ada, dengan nilai kredit masing-masing menuntut kinerja penyuluh tertentu sehingga penyuluh tersebut dapat dinaikkan jabatannya atau pangkatnya ketingkat yang lebih tinggi sesuai dengan batas minimal perolehan angka kreditnya sehingga menjadi motivasi dan pada akhirnya memenuhi kinerja yang diharapkan oleh lembaga penyuluhan.

Data tentang kepangkatan/golongan penyuluh pertanian yang ada dikabupaten konawe menunjukkan bahwa sebagian besar penyuluh pertanian memiliki golongan III yaitu 92 orang atau 70,77\%, selanjutnya golongan II yaitu 24 orang atau 18,46\%, dan hanya 14 orang atau $10,77 \%$ yang memiliki golongan IV. Hal ini diasumsikan bahwa proses kenaikan pangkat/ golongan penyuluh pertanian berjalan dengan baik sesuai dengan kemampuan dalam melaksanakan tugas atau presatasi yang dicapai sesuai dengan tugas pokok dan fungsi sesuai ketentuan yang berlaku. Prosedur kenaikan pangkat mengacu pada peraturan bersama Menteri Pertanian dan Kepala Badan Kepegawaian Negara No 54/Permentan/OT.210/11/2008 Nomor 23 A Tahun 2008 tentang Petunjuk Pelaksanaan Jabatan Fungsional Penyuluh Pertanian dan Angka Kreditnya disebutkan bahwa kenaikan pangkat melalui penetapan angka kredit adalah nilai dari tiap butir kegiatan dan atau akumulasi nilai butir-butir kegiatan yang harus dicapai oleh pejabat fungsional penyuluh pertanian dalam rangka pembinaan karir yang bersangkutan.

Pemberian kredit point terhadap butir-butir kerja penyuluh dalam penetapan angka kredit, macam butir kenaikan pangkat yang dinilai, jangka waktu kenaikan atau pengusulan kenaikan pangkat adalah hal-hal yang menjadi motivasi penyuluh untuk kenaikan pangkat dirinya yang berpengaruh pada motivasinya. Keputusan tersebut dimaksudkan untuk menjamin pembinaan karir, kepangkatan dan peningkatan profesional penyuluh pertanian melalui perkembangan tugas pokok jabatan fungsional penyuluh pertanian dan angka kreditnya. Dalam pelaksanaannya menuntut berbagai konsekuensi bagi para penyuluh pertanian yang telah diangkat dalam jabatan fungsional penyuluh pertanian.

Berdasarkan hasil penelitian, pengamatan, wawancara dan di lapangan menunjukkan bahwa faktor pendukung sebagaimana yang disebutkan di atas, tentunya tidak dapat dipungkiri adanya faktor penghambat kinerja penyuluh pertanian di Kabupaten Konawe diantaranya:

Pembinaan karir; untuk menjamin penyelenggaraantugaspemerintahandanpembangunan secara berdayaguna dan berhasilguna, diperlukan sistem pembinaan pegawai negeri sipil yang mampu memberikan keseimbangan terjaminnya hak dan kewajiban. Misi tiap satuan organisasi pemerintah 
untuk memotivasi kinerja pegawai negeri sipil perlu disusun pola karir yang memungkinkan potensi pegawai negeri sipil dapat dikembangkan seoptimal mungkin dalam rangka pencapaian misi organisasi pemerintah yang akhirnya pencapaian tujuan nasional dapat dilaksanakan secara lebih efektif.

Berdasarkan hasil penelitian wawancara, dan pengamatan di lapangan menunjukkan bahwa pembinaan karir dan prestasi kerja yang dilakukan terhadap penyuluh pertania di Kabupaten Konawe, yang berpedoman pada peraturan mentreri pertanian Nomor 13/ Permentan/ OT.140 / 3 / 2011 tentang Pedoman Penilaian Penyuluh Pertanian Teladan, belum berjalan secara baik disebabkan karena belum tersosialisaikan secara merata kepada penyuluh pertanian. Tolak ukur yang selama ini digunakan yaitu daftar penilaian pelaksanaan pekerjaan (DP3) yang cenderung bersifat subjektif. Demikian pula halnya penempatan seorang penyuluh sering tidak sesuai karir yang dimilikinya, sehingga cenderung penempatan penyuluh tersebut berdasarkan kemauan pejabat yang berwewenang.

Data perkembangan jumlah penyuluh pertanian yang diperoleh dari BP4K Kabupaten Konawe Tahun 2012 berdasarkan Keputusan Bupati Konawe No. 01 Tahun 2012 tentang penempatan penyuluh pertanian, perikanan dan kehutanan Kabupaten Konawe(Anonim, 2012) berjumlah 130 orang penyuluh pertanian, dimana pada tahun sebelumnya berjumlah 160 orang penyuluh, dan cenderung berkurang. Berdasarkan hasil wawancara menunjukkan bahwa berkurang jumlah penyuluh pertanian tersebut disebabkan karena adanya penyuluh yang pensiun, pindah kerja ke kabupaten lain dan ada pula yang pindah kejabatan struktural. Banyaknya penyuluh yang pindah kerja baik ke kabupaten lain dan kejabatan struktural, hal ini disebabkan selain karena permintaan sendiri atau dipromosikan oleh pengambil kebijakan untuk menduduki jabatan struktural tertentu, juga karena proses pembinaan karir yang tidak sesuai dengan kepangkatan dan senioritas, kemampuan, dan tingkat pendidikan tetapi lebih pada kedekatan dengan para pengambil kebijakan. Selain itu terungkap informasi bahwa rendahnya pembinaan karir penyuluh terutama dalam hal frekuensi mengikuti pelatihan selama kurung waktu 3 tahun yaitu sebanyak 122 orang penyuluh atau $93,85 \%$ dari 130 orang penyuluh pertanian menyatakan jarang mengikuti pelatihan, hal ini sebabkan oleh minimnya anggaran yang dikelola oleh BP4K.

Hasil penelitian juga didukung hasil penelitian Slamet (2010) yang menyatakan bahwa kebijakan kenaikan pangkat dan pola karir yang tidak jelas dan tidak sesuai dengan keinginan penyuluh akan menurunkan motivasi penyuluh. Lebih lanjut hasil penelitian ini sesuai dengan laporan Said (2001) menunjukkan bahwa pembinaan sistem karir maupun sistem prestasi kerja yang dilakukan selama ini kurang obyektif, sehingga harapan pemberdayaan PNS juga masih sulit dicapai. Untuk itu diperlukan pengukuran yang jelas dan obyektif tentang prestasi kerja seseorang, guna dapat membedakan penyuluh yang berprestasi dengan penyuluh yang tidak berprestasi. Hal ini sangat penting sehingga setiap penyuluh memiliki kepercayaan diri untuk berusaha berprestasi dalam melaksanakan tugas dan tanggungjawabnya.

Tingkat kepercayaan penyuluh terhadap kebijakan organisasi; berdasarkan hasil penelitian wawancara dan pengamatan dilapangan menunjukkan bahwa tingkat kepercayaan penyuluh terhadap kebijakan organisasi di Kabupaten Konawe, hubungannya kadang baik dan kadang tidak disebabkan karena seringnya bergantinya kebijakan misalnya perggantian kepala daerah atau kepala BP4K sehingga kebijakan pimpinan lama belum tentu sama atau melanjutkan kebijakan pimpinan baru, akibatnya mempengaruhi tingkat kepercayaan penyuluh pertanian. Hal ini didukung data di lapangan menunjukkan bahwa pada saat observasi sebelum penelitian ini dilakukan pada akhir tahun 2011 dan awal tahun 2012 saat penelitian berlangsung telah terjadi dua kali pergantian kepala BP4K Kabupaten Konawe.

Hasilpenelitian inididukung pendapatFeder et al.,(dalam Mardikanto, 2009) telah mengidentifikasi kendala yang dihadapi penyuluh dalam menjalankan tugasnya diantaranya komitmen dan dukunga politis yang berubah-ubah, terutama yang diakibat-kan oleh seringnya pergantian (pemegang) kekuasaan baik pada tingkat pusat maupun daerah. Hasil penelitian ini juga didukung hasil penelitian Rohmani (2001) yang menyatakan dari aspek organisasi permasalahan manajemen yang dihadapi oleh para penyuluh pertanian adalah adanya perubahan kebijakan penyelenggaraan penyuluhan, sistem pembinaan dan profesionalisme penyuluh melalui butir tugas pokok dengan angka kreditnya, restrukturisasi kelembagaan, fasilitas kerja maupun dana operasional. 
Kejelasan tugas/wewenang; seiring dengan pelaksanaan tugas dan fungsi (tupoksi) penyuluh pertanian yang telah tercatum dalam uraian kerja masing-masing tetapi terkadang tupoksitersebutselalu dipengaruhi oleh kebijakan pemerintah setempat sehingga tidak berjalan sebagaimana mestinya. Kejelasan tugas penyuluh secara umum telah ditetapkan oleh pemerintah dalam tupoksi yang secara spesifik tergambar dalam perhitungan angka kredit kenaikan pangkat, namun tidak dipungkiri bahwa sebagai aparat di daerah tidak dapat melepaskan diri dari kebijakan yang dibuat oleh pemerintahan daerah setempat. Karena itu, ada kemungkinan tugas-tugas lain dibebankan kepada penyuluh pertanian yang sebenarnya bukan merupakan tugas penyuluh tetapi merupakan tugas lain, seperti misalnya pengaturan dan pelayanan (Ibrahim, 2001).

Berdasarkan hasil penelitian, wawancara dan pengamatan di lapangan menunjukkan bahwa penyuluh pertanian di Kabupaten Konawe, selain melakukan kegiatan penyuluhan pertanian tetapi juga melakukan peran lain misalnya mendampingi penjabat, mendampingi proyek-proyek pemerintah lainnya (block Grant) dan bahkan menjadi tim sukses salah satu calon dalam pemilihan kepada daerah, sehingga tidak fokus pada tugas pokok yang menjadi tanggungjawabnya.

Hasil penelitian ini juga didukung hasil penelitian Sumardjo (1999) yang menyatakan bahwa selama ini kompetisi yang dimiliki oleh penyuluh lebih banyak diperuntukan untuk mengawal programprogram pemerintah, dengan demikian kompetensi untuk melaksanakan kegiatan sebagaimana yang telah direncanakan kurang dimanfaatkan. Hal ini sesuai dengan pendapat Rohmani (2001) yang menyatakan bahwa di negara kita penyuluh selain melakukan kegiatan penyuluhan tetapi juga melakukan peranan lain seperti menentukan kebijakan peraturan, atau pengawasan distribusi kredit yang sebenarnya bertentangan dengan tugasnya sebagai penyuluh pertanian. Hal senada, seperti hasil observasi yang dilakukan oleh Soewardi dan Sawit et al., dalam Anonim, 2000 memperlihatkan kelemahan sistem penyuluhan yang berlangsung pada saat ini adalah penyuluh pertanian didorong untuk melakukan berbagai usaha diluar tugas utama seperti mendampingi pejabat, mengurus benih dan tugas administrasi.

Rasio penyuluh dengan jumlah desa/ kelurahan binaan; rasio penyuluh pertanian dengan jumlah kelurahan/desa sejak diberlakukannya otonomi daerah terus mengalami pasang surut. Ada yang pensiun dan ada pula pindah kejabatan struktural, ditambah lagi dengan tidak adanya perekrutan penyuluh. Kondisi yang demikian itu menyebabkan jumlah penyuluh yang tidak seimbang dengan jumlah kelurahan/desa dalam suatu wilayah binaan penyuluh pertanian.

Berdasarkan kebijakan pemerintah tentang revitalisasi penyuluhan yang telah diundangkan dengan UU No.16/2006 tentang Sistem Penyuluhan Pertanian, Perikanan, dan Kehutanan (SP3K), dimana salah satu imp-lementasi dari kebijakan tersebut adalah perek-rutan petugas penyuluh baik sebagai PNS maupun sebagai tenaga harian lepas (THL) tenaga bantu penyuluh pertanian ditargetkan mencapai 10.000 orang pada tahun 2007 dan penempatan satu penyuluh untuk satu desa atau kelurahan (Anonim, 2005; 2009). Langkah ini cukup membantu memecahkan persoalan kekurangan penyuluh lapangan di daerah.

Berdasarkan hasil penelitian, wawancara dan pengamatan di lapangan menunjukkan bahwa penyuluh pertanian PNS di Kabupaten Konawe berjumlah 130 orang penyuluh, masih belum imbang dengan luas wilayah binaan yang mencapai 370 kelurahan/ desa, yang idelnya menurut undangundang SP3K, mengamanahkan satu penyuluh membina satu kelurahan atau desa. Dengan demikian, penyuluh pertanian dalam pelaksanaan tugas penyuluhan di Kabupaten Konawe melayani lebih dari satu kelurahan/desa binaan, sehingga implementasi UU No. 16/2006 tentang Sistem Penyuluhan Pertanian, Perikanan, dan Kehutanan (SP3K) dalam hal penempatan penyuluh satu desa/ kelurahan di wilayah penelitian belum terpenuhi (Anonim, 2006).

Hasil Penelitian ini juga sejalan dengan hasil penelitian Ibrahim (2001) yang mengatakan bahwa jika rasio penyuluh terhadap petani yang kecil tentu memperbesar tugas penyuluh dan rasio penyuluh yang besar memperingan tugas penyuluh. Pada rasio penyuluh per petani yang semakin besar diharapkan pelayanan penyuluhan kepada petani akan semakin baik.

\section{Kesimpulan}

Berdasarkan hasil penelitian dan pembahasan, 
maka dalam penelitian ini dapat ditarik kesimpulan bahwa tingkat kinerja penyuluh pertanian di Kabupaten Konawe masih pada kategori sedang. Lima indikator kinerja penyuluh pertania yang sering dilaksanakan dan paling penting adalah (1) menyusun programa penyuluhan pertanian, (2) menyusun rencana kerja dan jadwal kunjungan ke wilayah binaan, (3) membuat data dan peta wilayah binaan/wilayah kerja, (4) responsibilitas penyuluh dan (5) akuntabilitas penyuluh, sedangkan delapan indikator lainnya yaitu kadang-kadang dilaksanakan oleh penyuluh pertanian yaitu (1) mendiseminasikan informasi teknologi (penggunaan metode penyuluhan pertanian yang tepat), (2) memberdayakan dan memandirikan pelaku utama, (3) menjalin kemitraan usaha dengan unsur-unsur terkait yang dapat mendukung suksesnya usahatani, (4) mewujudkan akses pelaku utama ke lembaga keuangan, sumbersumber informasi, sarana produksi dan pemasaran hasil, (5) responsivitas penyuluh pertanian, (6) kualitas penyuluh pertanian, (7) efisiensi penyuluh pertanian, dan (8) efek-tivitas penyuluh pertanian. Hal ini berarti penyuluh pertanian belum sepenuhnya menerapkan indikator kinerja secara utuh (kadangkadang menerapkan).

Meskipun tingkat kinerja penyuluh pertanian masih tergolong sedang, namun upaya yang dilakukan pemerintah Kabupaten Konawe dalam pemberdayaan penyuluh pertanian sudah cukup baik yaitu adanya beberapa faktor pendukung misalnya adanya insentif dalam bentuk piagam penghargaan, kepercayaan petani terhadap penyuluh pertanian dan proses kenaikan pangkat (kepangkatan), namun demikian tidak dapat dipungkiri adanya beberapa faktor penghambat misalnya: pembinaan karier, tingkat kepercayaan penyuluh terhadap kebijakan organisasi, kejelasan tugas/wewenang, dan rasio penyuluh dengan jumlah desa/kelurahan binaan.

\section{Daftar Pustaka}

Anonim, 2000. Prosidum Lokakarya Nasional Penyebaran Inovasi Pertanian Era Otonomi Daerah. Jakarta (ID): Departemen Pertanian. 2005. Pencanangan Revitalisasi Penyuluhan

Pertanian. Edisi 14-20 Desember 2005, No. 3128 Tahun XXXIV. Jakarta (ID): Sinar Tani. 2006. Undang-Undang Republik Indonesia. Nomor 16 Tahun 2006. Tentang
Sistem Penyuluhan Pertanian, Perikanan, dan Kehutanan. . 2009. Masa Depan Penyuluah Pertanianan dan Pedesaan. Edisi 29 April 5 Mei 2009, No. 3301 Tahun XXXIX. Jakarta (ID): Sinar Tani. 2011. Programa Penyuluhan Kabupaten Konawe. Badan Pelaksana Penyuluhan Kabupaten Konawe. Konawe (ID): Unaha.

2011. Peraturan Menteri Pertanian Nomor: 13/Permentan/OT.140/3/2013. Tentang Pedoman Penilaian Penyuluh Pertanian Teladan. Jakarta (ID).

. 2012. Keputusan Bupati Konawe Nomor:

01 Tahun 2012. Tentang Penetapan Penyuluh Pertanian, Perikanan dan Kehutanan Kabupaten Konawe. Konawe (ID).

Arnold HJ, DC Feldman. 1986. Organizational Behavior. McGraw-Hill Book Company. New York.

As'ad M. 1991. Psikologi Industri. Yogyakarta (ID): Ed Library.

AtmosudirjoP.EkologiAdministrasi, Pengembangan SDM, Perencanaan dan Pengembangan Karir. Jakarta (ID): Ramdhan Cipta, Grafika.

Badan Kepegawaian Negara. 2008. Peraturan Bersama Menteri Pertanian dan Kepala Badan Kepegawaian Negara No. 54/Permentan/ OT.210/11/2008. Tentang Petunjuk Pelaksanaan Jabatan Fungsional Penyuluh Pertanian dan Angka Kreditnya. Jakarta (ID).

Ban VD, Hawkins HS. 1999. Penyuluhan Pertanian. Kanisius. Yogyakarta (ID).

Bernardin HJ, JEA Russel. 1998. Human Resources management. Edisi 2. Mc Graw-Hill. International. Edition.

Bestina. 2001. Kinerja Penyuluh Pertanian dalam Pengembangan Agribisnis Nenas. (Penelitian Studi Kasus di Kec. Tambang Kab. Kampar).

Blumberg M, Charles DP. 1982. The missing opportunities in organizational research: Some Implications for a theory of work performance. Academy of management Review. 7(4): 560569.

Davis K, W Newstrom. 1989. Human Behavior at Work, Organizational Behavior (Eighth Edition). Mc Graw Hill Book Company. New York.

Deptan. 2010. Buku Kerja Penyuluh Pertanian. Departemen Pertanian. Jakarta (ID). 
Fardiaz D, Hartaman J, Armanto A. 1999. Modul analisis SWOT. Lokakarya partisipatif. Badan Penelitian dan Pengembangan Pertanian. Deptan. Jakarta (ID).

Fukuyama F. 2002. Trust. Kebajikan Sosial dan Penciptaan Kemakmuran. Qalam. Yogyakarta (ID).

Hamzah I. 2011. Faktor Penentu Kinerja Penyuluh Pertanian di Kota Tidore Kepulauan Provinsi Maluku Utara. (tesis). Sekolah Pascasarjana IPB. Bandung (ID).

Hasibuan HM. 2000. Manajemen Sumber Daya Manusia: dasar kunci keberhasilan. Haji Masagung. Jakarta (ID).

Hill CJ, Lynn. LEJ. 2004. “Is hierarchical governance in decline?. Evidence from empirical research. Journal of public administration Theory.

Huda N, Sumardjo, Slamet M, Tjitropranoto P. 2009. Pengembangan Kompetensi Penyuluhan Pertanian Dalam Pendidikan Jarak Jauh Universitas Terbuka: Kasus Alumni UT di Wilayah Serang, karawang, Cirebon, dan Tanggamus. Jurnal komunikasi Pembangunan. Juli 2009. 07(2).

Husni J. 2010. Kinerja Penyuluh Pertanian Lapangan di Provinsi Jambi. Jurnal Penelitian Universitas Jambi. 12(2).

Ibrahim JT. 2001. Kajian Reorientasi Penyuluhan Pertanian Ke Arah Pemenuhan Kebutuhan Petani di Provinsi Jawa Barat. Bogor (ID): Program Pascasarjana IPB.

Ingraham PW, PG Joyce, AD Donahue. 2003. Government Performanc: Why Management matters. Baltimore, MD: John Hopkins University Press.

Jahi A, Leilani A. 2006. Kinerja Penyuluh Pertanian di Beberapa Kabupaten Provinsi Jawa Barat. Jurnal penyuluhan September 2006. 2(2). Bogor (ID).

Jamal H. 2010. Kinerja Penyuluh Pertanian Lapangan di Provinsi Jambi. Jurnal Penelitian Universitas Jambi. 12(2). Juli 2010. Bogor. (ID) Keban, Yeremias T. 2004. Enam Dimensi Strategis Administrasi Publik: Konsep, Teori dan Isu. Yogyakarta (ID): Gaya media.

Kusnadi D, Purnamawati L. 2010. Kinerja Penyuluh Pertanian dalam Melaksanakan Tugas Pokok dan Fungsinya Menurut Pesepsi Petani. Jurnal Penyuluhan Pertanian. 5(2) Tahun 2010. Bogor.
Lenvine, CIIDG Peter, FJ Thompson. 1990. The New Public Managemen in Action. Oxford New York. University Press.

Luthaus C, Andrien MH. 1998. Organization Assessment: A Review of Experience. Universalia Occasional Paper N0. 31, Oktober 1998.

Mahmudi, Mardiasmo. 2004. Pengaruh Kinerja Pemerintah Daerah dalam Era Otonomi Daerah: Suatu Studi Kasus Sleman, Daerah Istimewa Yogyakarta. Sosio Sain. 17(1). Januari.

Mardikanto T. 2008. Refleksi dan Rekomendasi Implementasi penyuluhan Pembangunan Pertanian. dalam Yustina I, Sudradjat A, Penyunting. Pemberdayaan manusia Pembangunan yang Bermanfaat. Medan (ID): Pustaka Bangsa Press.

2009. Sistem Penyuluhan Pertanian. Lambaga Pengembangan Pendidikan (LPP) dan UPT. Surakarta (ID): UNS Press.

Marius JAS, Margono S, Asngari PS. 2006. Pengaruh Faktor Internal dan Eksternal Penyuluh Terhadap Kompetensi Penyuluh di Nusa Tenggara Timur. Jurnal pertanian Edisi September 2006.

Moleong. 1998. Metode Penelitian Kualitatif. Bandung (ID): Remaja Rosda Karya.

Mokhtar SM. 2001. Kinerja Lembaga Penyuluhan Pertanian dan Adopsi Inovasi Kedelai serta Implikasi pada Pelaksanaan Otoda di Kab. Kotawaringin Timur. (tesis). Program Pasca Sarjana UGM. Yogyakarta (ID): Universitas Gadjah Mada.

Prayudi A. 1997. Pengembangan visi dan Reorientasi Kinerja Aparatur Daerah, menjawab tantangan masyarakat baru. Buletin, Manajemen pembangunan (19) Tahun V April 1995. Bappenas. Jakarta (ID).

Rahardja AT. 2004. Hubungan Antara Komunikasi Antar Pribada Guru dan Motivasi Kerja Guru Dengan Kinerja Guru SMUK BPK Penabur Jakarta. Jurnal Pendidikan Penebar-No.03/ Th.III/Desember 2004.

Rohmani SA. 2001. Kinerja Penyuluh Pertanian Dalam Pelaksanaan Tugas Pokoknya. (tesis). Program Pasca Sarjana IPB. Bandung (ID).

Safitri KT 2008. Pengaruh Insentif Berbasis Kinerja Terhadap Prestasi Kerja Dengan Evaluasi Anggaran Sebagai Variabel Intervening (Survei pada Pegawai Pemerintah Sragen dan Boyolali). Universitas Muhammadiyah Surakarta. 
Said I. 2001. Pemberdayaan Sumber Daya Pemerintah Ditinjau dari Sudut Hukum Kepegawaian. Analisis (4), Oktober 2001.

Simamora H. 1999. Manajemen SDM. Bagian penerbitan. STIE YKPN. Yogyakarta (ID).

Slamet. 2010. Teori Organisasi. Bogor (ID): Sekolah Pascasarjana Institut Pertanian Bogor.

Sugiono. 2007.Statistik untuk Penelitian. Bandung (ID): Alfabeta.

Suhanda, Nani S, Jahi A, dkk. 2008. Kinerja Penyuluh Pertanian di Jawa Barat. Jurnal Penyuluhan. 4(2). Desember 2008.

Suhanda, Nani S, Jahi A, Sugihen BG, Susanto D. 2008. Kinerja Penyuluh Pertanian di Jawa Barat. Jurnal Penyuluhan. September 2008. 4(2).

Sumardjo. 1999. Transformasi Model Penyuluhan Pertanian. Menuju Pengembangan Kemandirian Petani (Kasus di Provinsi Jawa Barat). Disertasi Doktor. Bogor (ID): Sekolah Pascasarjana Institut Pertanian Bogor.

. 2010. Penyuluhan Menuju Pengembangan Kapital Sosial Dalam Mewujudkan Kesejahteraan Rakyat. Orasi Ilmiah Guru Besar Dalam Rangka dies Natalis IPB ke-47. IPB. Bogor (ID).

Supandi S. 2002. Membangun Kompetensi Belajar. Jakarta (ID): Departemen Pendidikan Nasional. Suwito. 2005. Pengaruh Kemampuan, Orientasi Tujuan, Kepribadian, dan Motivasi dalam Self Efficacy dan Penetapan Tujuan terhadap Kinerja. (tesis). Yogyakarta (ID): Program Pasca Sarjana UGM.
Swanson, Burton E, Bents, Robert P, Sofranko, Andrew J. 1997. Improving Agricultural Ektension. Food Agriculture Organization of the United Nations. Home.

Stonner JAF, Freeman RE. 1992. Manajemen (terjemahan). Edisi Keempat. Jakarta (ID): Intermedia.

Tashakkori A, Taddlie C. 1998. Mixed Methodology Combining Qualitative and Quantitative Approaches. Sage Publication In, Thousand Oaks, California.

Tjitropranoto P. 2005. Penyuluhan Pertanian masa Kini dan Masa depan. Dalam Membentuk Pola Perilaku manusia pembangunan. Diedit Oleh Ida Yustina dan Adjat Sudrajat. IPB Press. Bogor.

Umstot DD. 1988. Understanding Organizational Behavior. West Publishing Company. New York. Utama, Wahyu, Bekti, Widiawati,Emi, Wibowo, Agung. 2008. Kinerja Penyuluh Pertanian Lapang (PPL) Dalam Pengembangan Beras Organik Menuju terwujudnya kabupaten Sragen Sebagai Sentra Beras Organik. Jurnal Agritexts (24) Desember, 2008. UNS Solo.

Vroom V. 1964. Work and Motivation. Wiley. New York.

Yusri A. 1999. Faktor-Faktor yang Mempengaruhi Persepsi Petani terhadap Kredibilitas Penyuluh Pertanian. [tesis]. Bogor(ID): Program Pascasarjana Institut Pertanian Bogor. 